\title{
THE EFFECT OF HANDLING AND TRANSPORT \\ ON THE CONCENTRATION OF GLUCOSE AND CORTISOL IN BLOOD PLASMA OF COMMON CARP
}

\author{
Z. SVOBODOVÁ ${ }^{1,2}$, P. KALÁB ${ }^{1}$, L. DUŠEK ${ }^{3}$, B. VYKUSOVÁ ${ }^{2}$, \\ J. KOLÁR̆OVÁ ${ }^{2}$, D. JANOUŠKOVÁ ${ }^{4}$ \\ ${ }^{1}$ University of Veterinary and Pharmaceutical Sciences, Brno \\ ${ }^{2}$ University of South Bohemia, Research Institute of Fish Culture and Hydrobiology, Vodňany \\ ${ }^{3}$ RECETOX, Masaryk University, Faculty of Natural Sciences, Brno \\ ${ }^{4}$ University of South Bohemia, Faculty of Agriculture, České Budějovice \\ Received September 15, 1998 \\ Accepted October 25, 1999
}

Abstract

Svobodová Z., P. Kaláb, L. Dušek, B. Vykusová, J. Kolářová, D. Janoušková: The Effect of Handling and Transport on the Concentration of Glucose and Cortisol in Blood Plasma of Common Carp. Acta Vet. Brno 1999, 68: 265-274.

The aim of this contribution was to assess the degree of stress in common carp (Cyprinus carpio, L.) exposed to handling and transport. Cortisol and glucose concentrations in blood plasma were used as stress indicators. In some cases, concentration of ammonia in blood plasma and relative weight of spleen (SSI) were used as well. Within handling, an effect of time pause ( $0 ; 2$ and $5 \mathrm{~min}$ ) between catching the fish from water and blood sampling for stress indicators was checked. Another goal was to assess the effect of Menocain anaesthetics on the stress indicators. An open system of a 10-hour transport in a special long-distance live fish transport truck (Transport I a II), and a 2-hour transport in classic transporting tanks (Transport III) were compared. Temperature and oxygen concentration in water was measured during transport. After handling the fish prior to blood sampling ( 2 and 5 min pause), the cortisol concentration dropped significantly $(\mathrm{p}<0.001)$ and the glucose concentration significantly $(\mathrm{p}<0.001)$ increased compared to values in fish sampled immediately after catching. No effect of anaesthetics on cortisol concentration was proved. On the contrary, the glucose concentration fell $(\mathrm{p}=0.012)$ in the anaesthetized fish. After a 10 -hour transport in a special truck (Transport I), a significant $(\mathrm{p}<0.001)$ decrease of the cortisol concentration was found, as well as a significant $(\mathrm{p}<0.001)$ increase in the glucose concentration in blood plasma. In the course of 10 hour transport in a special truck (Transport II), the majority of carp was found dead. Suffocation and ammonia autointoxication due to loading the fish with full digestive tract were the most probable causes of the fish mortality. After a 2-hour transport in transporting tanks (Transport III) both the cortisol concentration and relative weight of spleen (SSI) dropped non-significantly while glucose concentration in blood plasma significantly $(\mathrm{p}<0.001)$ increased. Results showed that both handling and transport are important stressors in the common carp. Preventive measures were proposed aimed at alleviating the negative effects of these stressors.

Cyprinus carpio L., stress, anaesthesia, ammonia, SSI

Commercially important fish species, as well as those living in open waters are being exposed to various stresses in the course of their life. Common stressors are e.g. water level decrease (Fryer 1975; Thomas and Roberts on 1991), fish catching in nets (Barton et al. 1980), increased stocking density (Barton et al. 1985), water temperature change (Barton and Peter 1982), artificial and natural reproduction (Hlavová 1992; Lusková and Lusk 1995ab; Svobodová et al. 1997b), fish handling (Wurts 1995), etc. Functioning of these effects was observed above all in salmonids and marine fish (Barton et al. 1980, 1985; Wagner and Driscoll 1994; Lusková and Lusk 1995b; Olsen et al. 1995). Assessment of stressors of common carp in the course of rearing is less frequent ( Smith and Hattingh 1978; Jeney et al. 1984; Spurný et al. 1984, 1987; Lebedeva et al. 1989; Jeney and

Address for correspondence:

Prof. MVDr. Zdeňka Svobodová DrSc.

Prof. MVDr. Zdeňka Svobodová DrSc.
Research Institute of Fish Culture and Hydrobiology
Zátiší 728/II

38925 Vodñany, Czech Republic
Phone: +420342382402

Fax: + 420342382396

ova@vurh.jcu.cz 
Jeney 1992; Chen et al. 1995; Yin et al. 1995; Svobodová et al. 1998). The goal of the studies described hereby was to search for and direct the attention to some critical phases of the rearing cycle and thus to create prerequisits to minimize the stress (S vobodová et al. 1997c).

Various biochemical and haematological indices are used to indicate and assess the effect of stressors in fish. Indices used are e.g. concentration of glucose, cortisol, lactate, ammonia and chlorides in blood plasma, haematocrit value and mean corpuscular volume, relative weight of spleen, etc. (Thomas 1990; Palíková and Svobodová 1995; Spurný and Mareš 1997). Concentrations of cortisol and glucose are considered among the most important stress indicators in fish. A short-term intensive stress leads to a large increase of the cortisol concentration followed by a slow decrease (Barton et al. 1980). The concentration of glucose has a similar course but with a certain delay (B arry et al. 1993; Carragher and Ress 1994).

We utilized these indices (cortisol, glucose) in the present study to assess the stress of the common carp exposed to experimental handling and transport under field conditions, as well as for the assessment of anaesthesia.

\section{Material and Methods}

The effects of handling, anaesthesia and transport on the concentration of cortisol and glucose in blood plasma, or on other indices (relative weight of spleen - SSI and ammonia concentration in blood plasma) were studied in the common carp (Cyprinus carpio L.).

\section{Handling}

The effect of time pause ( $0 ; 2$ and $5 \mathrm{~min})$ between catching the fish in water and blood sampling for stress indicators was checked. A total of 30 common carp (live weight $479 \pm 30.8 \mathrm{~g}$ ) were caught from a pond (water temperature $20^{\circ} \mathrm{C}$, oxygen saturation 95\%), and placed into a 3001 tank with pond water (water temperature 20 ${ }^{\circ} \mathrm{C}$, oxygen saturation 90\%). Immediately after catching in the tank, blood was sampled from 10 specimen. Blood of another 10 specimen was sampled after keeping them in the air for $2 \mathrm{~min}$, and the remaining 10 specimen were sampled after keeping in the air for 5 min. Fish were kept in a small hanging net in order to minimize their movements. The experiment was performed on July 3, 1995.

Anaesthesia

For the common carp anaesthesia, Menocain was used at a concentration of $0.2 \mathrm{~g} \cdot \mathrm{l}^{-1}$ for $10 \mathrm{~min}$. The effective substance of Menocain is (3-ethoxycarbonylfenyl) ammonium natrium hydrogensulphuricum in $50 \%$ amount and with natrium chloratum as the remaining 50\% (Král and Svobodová 1990). A total of 20 common carp individuals (live weight $672 \pm 22.5 \mathrm{~g}$ ) were caught from a pond (water temperature $20^{\circ} \mathrm{C}$, oxygen saturation $90 \%$ ) and placed in two 3001 tanks with the pond water of the same indices, 10 fish into each tank. The 10 specimen in one tank were anaesthetized and blood-sampled. The other 10 specimen in the second tank were used as a control group without anaesthesia. The experiment was performed on July 7, 1995.

Transport

Fish transport was performed in an open system of live fish transport as follows: Transports I and II in a special truck for long-distance live fish transport and Transport III in classic transporting tanks. In the special truck for long-distance live fish transport, the water was enriched with gas oxygen released from a liquid oxygen container. In the classic transporting tank, the water was aerated with air produced by the truck compressor. Three-year-old marketable common carp were used in Transports I and II whereas two-year-old stock of common carp was used in Transport III. The stocking density of fish in transporting tanks was $300 \mathrm{~kg} / \mathrm{m}^{3}$ in Transports I and II and $250 \mathrm{~kg} / \mathrm{m}^{3}$ in Transport III. Water temperature and oxygen saturation at the beginning and at the end of each transport are given in Table 1.

Table 1

The water temperature and oxygen saturation within the course of a transport

\begin{tabular}{|l|c|c|c|c|}
\hline Transport & \multicolumn{2}{|c|}{ Beginning } & \multicolumn{2}{c|}{ End } \\
\hline & Temperature ${ }^{\circ} \mathrm{C}$ & Oxygen $\%$ & Temperature ${ }^{\circ} \mathrm{C}$ & Oxygen \% \\
\hline I & 16 & 150 & 14 & 40 \\
\hline II & 15 & 140 & 16 & 25 \\
\hline III & 9 & 82 & 13 & 20 \\
\hline
\end{tabular}


Prior to Transport I (May 11, 1995) the fish were loaded into the truck from a storage pond with deeply decreased water level. Twenty specimen of live weight $1487 \pm 370.9 \mathrm{~g}$ from the storage pond were caught for blood sampling. Transport I lasted for 10 hours. Afterwards, 20 specimen of live weight $1810 \pm 286.4 \mathrm{~g}$ were caught by a dip net directly from the truck and sampled for blood. Prior to the Transport I, fish had been kept in the storage pond for 3 days without feeding and their digestive tract was empty.

On the contrary, the common carp used in Transport II (July 10,1996) were caught from a production pond one day prior to the transport and partly even on the day of the transport. Feeding was performed in the pond and fish were caught at feeding pits. The pond water temperature was about $20^{\circ} \mathrm{C}$, whereas in the storage pond where the fish were transferred to, it was $15^{\circ} \mathrm{C}$. Water level in the storage pond was decreased and oxygen saturation was $16 \%$. Fish used emergency breathing. At this stage, they were handled to a special truck for long- distance live fish transport. Prior to transport, twenty specimens of live weight $1432 \pm 265.0 \mathrm{~g}$ were blood-sampled. Heavily filled digestive tracts were found in 7 specimens and remnants of chyme were found in 13 specimens. The transport had to be interrupted after 10 hours. The majority of the fish stock in the truck was found dead. Six living specimens of live weight $1340 \pm 112.0 \mathrm{~g}$ were blood-sampled, and remnants of chyme were found in their digestive tract.

The Transport III was performed on April 2, 1997. Two-year-old fish taken directly during a pond harvest were transported and stocked into another pond. The transport, lasting for 2 hours, was performed in classic transporting tanks. Blood was sampled from 15 specimen of live weight $200 \pm 96.2 \mathrm{~g}$ during the pond harvest and from another 15 specimen of live weight $192 \pm 64.4 \mathrm{~g}$ after terminating the transport before stocking them into the other pond.

Fish blood was sampled by cardiopunction, using a heparinized needle. Heparin at a concentration of 50 I.U. in

$1 \mathrm{ml}$ of blood was used as an anticoagulant (Svobodová et al. 1991).

The cortisol concentration in blood plasma was assessed by radioimmunoassay by means of a kit by Immunotech Comp. The glucose concentration was determined spectrophotometrically by means of BIO-LACHEMA OXOCHROM glucose kit. Other stress indices were determined, such as the ammonia concentration in blood plasma by an enzymatic kit by Boehringer (in Transport II) and the relative weight of spleen (Transport III).

The water temperature and oxygen saturation was determined by WTW oxymeter (Germany). Statistical analyses of results were perfomed by $t$-test, Mann-Whitney $U$-test and by one-way ANOVA.

\section{Results}

\section{Handling}

Fig. 1 shows the comparison of cortisol and glucose concentrations in blood plasma of the common carp blood-sampled immediately after catching and after 2 and/or 5 min period in the air. As analysed by t-test and Mann-Whitney test, the time periods of 2 and 5 minutes between catching and blood sampling were reflected in significantly decreased cortisol concentration (by $40 \%$ ) and increased glucose concentration (by $45 \%$ ) in analysed blood plasma samples (both results significant at the level $\mathrm{p}<0.001$ ). Concentration of cortisol correlated negatively with concentration of glucose in fish analysed 2 and 5 minutes after catching $(\mathrm{r}=-0.662, \mathrm{p}<0.001)$ (Fig. 2). No significant correlation was found between the cortisol and glucose concentration in fish analysed immediately after catching.

\section{Anaesthesia}

The values of cortisol and glucose concentrations in blood plasma of control fish well as of those anaesthesized with Menocain are given in Fig. 3. No significant differences were found in the cortisol concentration of the compared groups of fish $(t$-test: $p=0.854)$, values measured were practically identical. On the contrary, the glucose concentration was found significantly higher in the control non-anaesthetized group (by $28 \% ; t$-test: $p=0.012$ ) compared to the anaesthetized fish.

\section{Transport}

Prior to Transport I, the cortisol concentration in blood plasma of the common carp was $1242 \pm 197 \mu \mathrm{mol} \cdot \mathrm{l}^{-1}$, significantly dropping within the 10-hour transport to $803 \pm 226$ $\mu \mathrm{mol} \cdot \mathrm{l}^{-1}$ (Fig. $\left.4 \mathrm{a}\right)$, i.e. by $35 \%$ ( $t$-test: $\left.\mathrm{p}<0.001\right)$. On the other hand, the glucose concentration significantly increased during this transport from $4.42 \pm 1,28 \mathrm{mmol} \cdot \mathrm{l}^{-1}$ to $7.24 \pm 2,15 \mathrm{mmol} \cdot \mathrm{l}^{-}$ 1 (Fig 5a), i.e. by 63\% ( $t$-test: $\mathrm{p}<0.001)$. At the end of the transport the fish did not show any signs of clinical or pathoanatomical changes.

After a 10-hour Transport II, the majority of the fish was found dead. Fish gathered in the 

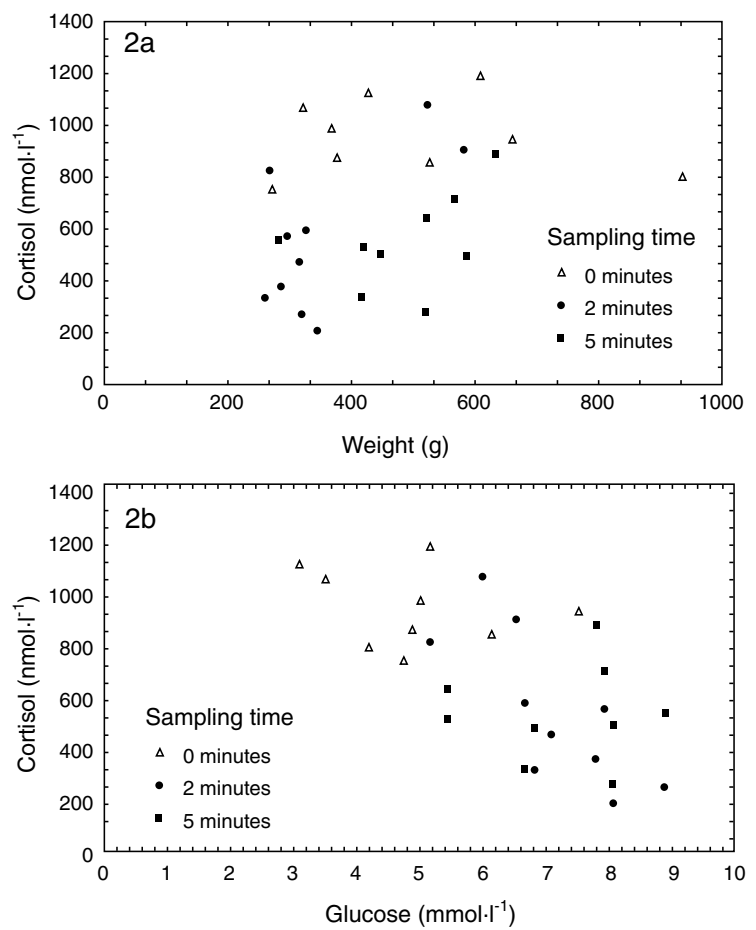

Fig.1.: Concentrations of cortisol and glucose in blood plasma of the common carp. Blood sampled immediately after removal the fish from water (0), after $2 \min (2)$ and/or $5 \min (5)$ keeping the fish in the air.

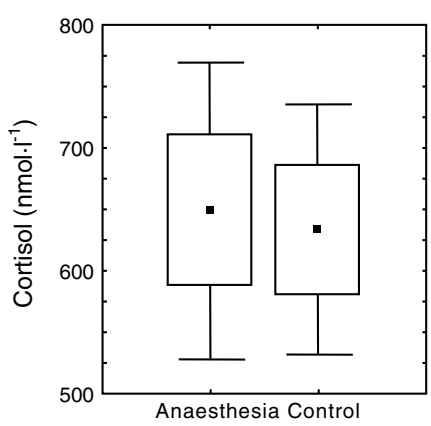

工 $95 \%$ Conf. limits

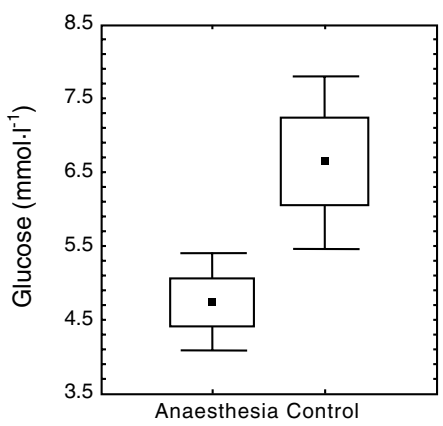

Stand. error

- Mean

Fig.2.: Correlation between concentrations of cortisol and of glucose in blood plasma of the common carp with blood sampled immediately after removal the fish from water, after $2 \mathrm{~min}$ and/or $5 \mathrm{~min}$ keeping the fish in the air.

storage pond prior to the transport were found emergency-breathing, post mortem examination performed after blood sampling showed heavily filled digestive tracts in 7 specimens and remnants of chyme in 13 specimens. Live fish after the transport used emergency breathing again. Six living specimens analyzed were found with remnants of chyme in their digestive tract. The cortisol concentration in blood plasma of the 13 

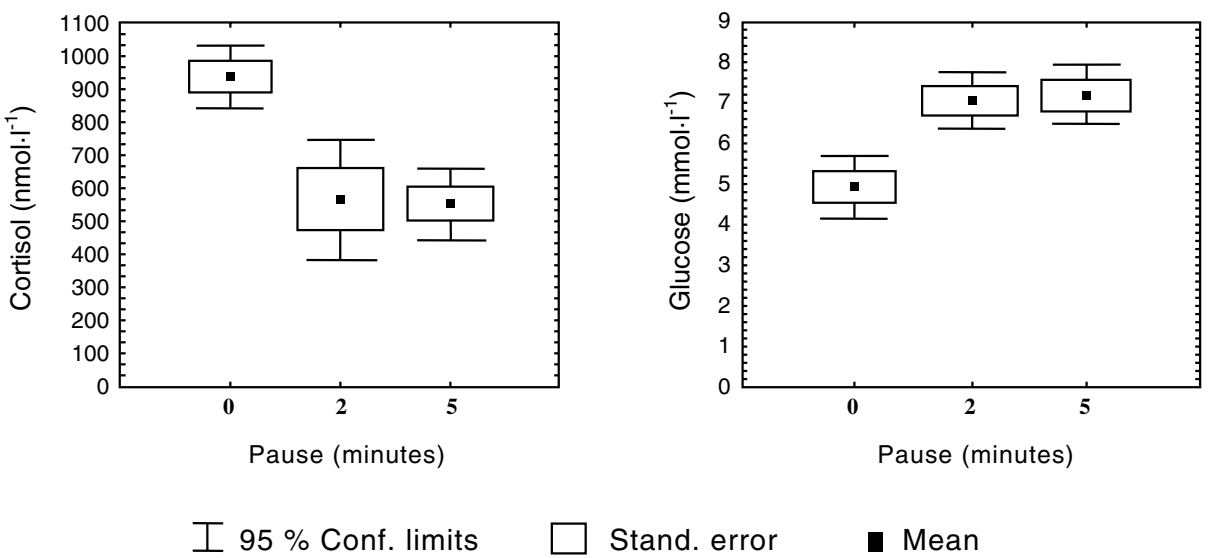

Fig.3.: Concentrations of cortisol and of glucose in blood plasma of the control and anaesthetised common carp.
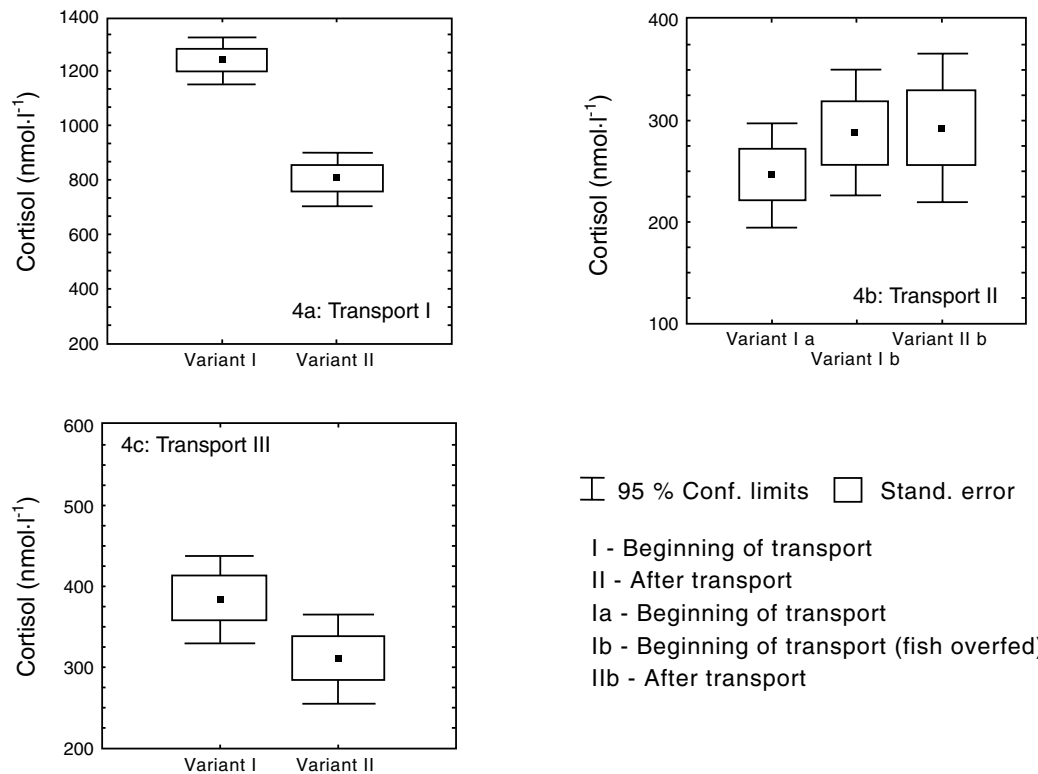
工 $95 \%$ Conf. limits $\square$ Stand. error
I - Beginning of transport
II - After transport
la - Beginning of transport
$\mathrm{lb}$ - Beginning of transport (fish overfed)
Illb - After transport

- Mean

Fig.4.: The concentration of cortisol in blood plasma of the common carp before and after Transport I, II and III.

specimens with presence of chyme remnants in the digestive tract prior to transport was $245.4 \pm 95.0 \mu \mathrm{mol} \cdot \mathrm{l}^{-1}$ whereas in the 7 specimen with heavily filled digestive tracts it reached $286.9 \pm 83.1 \mu \mathrm{mol} \cdot \mathrm{l}^{-1}$. These differences were not significant (ANOVA: $p=0.334$ ). Similarly, no difference was found in the cortisol concentration of the common carp before and after the Transport II (346 $\pm 151 \mu \mathrm{mol} . \mathrm{l}^{-1}$, ANOVA: $\left.\mathrm{p}=0.486\right)$ (Fig. 4b). Fig. 5b shows values of the glucose concentration in blood plasma of the fish with the chyme remnants in the digestive tract $\left(6.8 \pm 1.1 \mathrm{mmol} \cdot \mathrm{l}^{-1}\right)$, and of those with heavily filled digestive tracts $\left(9.9 \pm 1.6 \mathrm{mmol} \cdot \mathrm{l}^{-1}\right)$ before the transport and after the 10 -hour transport $(31.83 \pm 14.54$ $\left.\mathrm{mmol} \cdot \mathrm{l}^{-1}\right)$. Significantly higher glucose concentrations in blood plasma were found before 

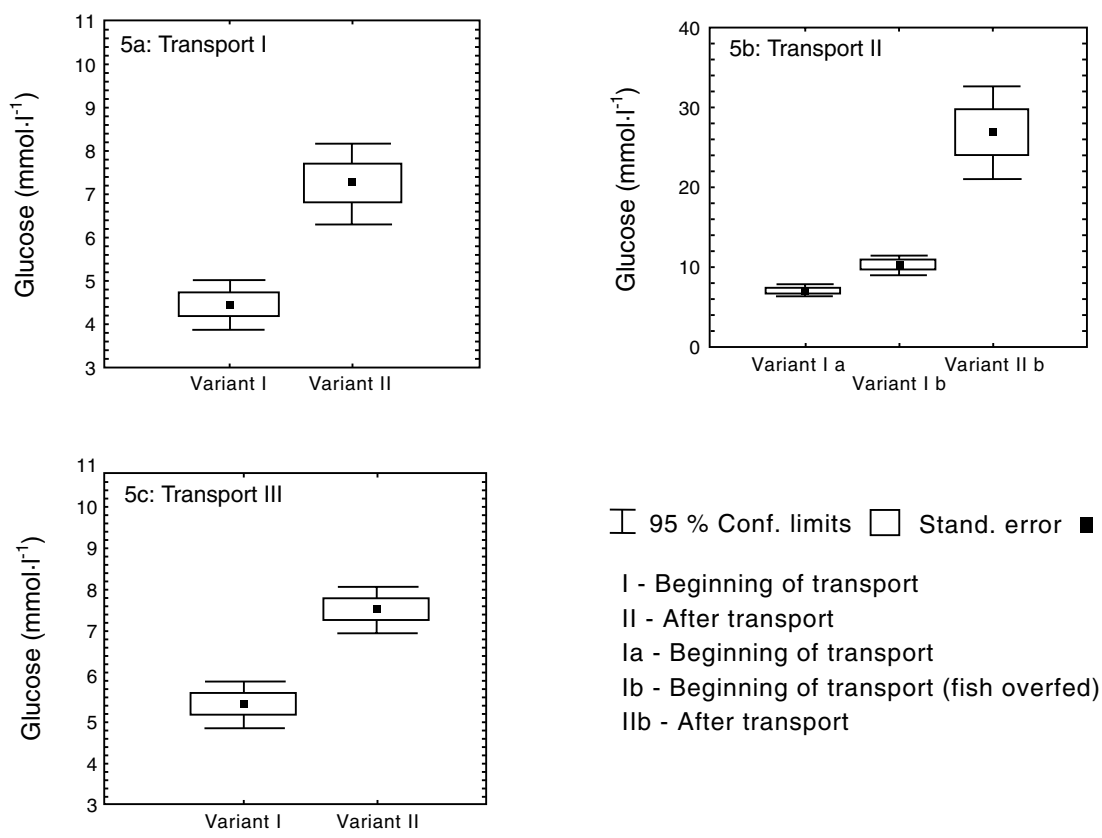

\author{
I $95 \%$ Conf. limits $\square$ Stand. error $\square$ Mean \\ I - Beginning of transport \\ II - After transport \\ la - Beginning of transport \\ lb - Beginning of transport (fish overfed) \\ Ilb - After transport
}

Fig.5.: The concentration of glucose in blood plasma of the common carp before and after Transport I, II and III.

the transport in the group of fish with heavily filled digestive tract compared to those with chyme remnants in the tract (ANOVA: $\mathrm{p}=0.042$ ). A highly significantly increased glucose concentration in blood plasma occurred in fish after the 10-hour transport compared to both groups of fish before the transport (ANOVA: $p<0.001$ ). The concentration of ammonia in blood plasma was determined in fish analysed before and after the Transport II with the following values:

Fish group before the transport $(n=13)(A)$ digestive tract with chyme remnants $398 \pm 61.7 \mathrm{mmol} \cdot \mathrm{l}^{-1}$

Fish group before the transport $(n=7)(B)$ digestive tract heavily filled $696 \pm 112.1 \mathrm{mmol} \cdot \mathrm{l}^{-1}$

Fish group after the transport $(n=6)(C)$ digestive tract with chyme remnants $413 \pm 173.7 \mathrm{mmol} \cdot \mathrm{l}^{-1}$.

Significant differences in the ammonia concentration in blood plasma were found between groups A and B, B and C (ANOVA: $\mathrm{p}<0.001)$. This indicated that the ammonia concentration was markedly higher in blood plasma of fish with heavily filled digestive tracts.

Transport III lasted for 2 hours and it was performed in classic transport tanks. Values of cortisol and glucose concentrations in blood plasma of two-year-old common carp before and after the transport are given in Fig. $4 \mathrm{c}$ and 5c. The cortisol concentration decrease from $382.7 \pm 106.7 \mu \mathrm{mol} \cdot \mathrm{l}^{-1}$ before the transport to $308.2 \pm 108.5 \mu \mathrm{mol} \cdot \mathrm{l}^{-1}$ after it, i.e. by $19 \%$ was inexpressive ( $t$-test: $\mathrm{p}=0.071)$. On the contrary, the increase of glucose values from the concentration of $5.37 \pm 1.08 \mathrm{mmol} \cdot \mathrm{l}^{-1}$ before the transport to $7.60 \pm 1.07 \mathrm{mmol} \cdot \mathrm{l}^{-1}$ after it, i.e. by $42 \%$ was a significant one $(t$-test: $\mathrm{p}<0.001)$. Moreover, another parameter was used to assess the stress level in fish in the Transport III and this was the relative weight of spleen (SSI). In the course of this transport, values of this variable dropped from $0.40 \pm 0.105 \%$ to $0.34 \pm 0.068 \%$. However, this decrease was not significant. 


\section{Discussion}

In the stress scheme by Selye (1956), stress is regarded rather as a basic component of a normal metabolism than a deviation from normal status. Wedemeyer and McLeay (1981) also defined stress in fish as a summary of physiological reactions occurring when an animal tries to maintain its homeostasis. In the first phase of organism's response to the effect of stressors, endocrine changes appear as primary reactions, considering, above all, the catecholamins and glucocorticoids. They are utilized in controlling the organism and they cause metabolic and osmotic changes, health changes and other changes considered as secondary ones (Mazeaud et al. 1977; Pickering 1981; Gratzek and Reinert 1984; Leatherland and Woo 1998). Secondary reactions in our study were represented by changes in concentrations of glucose and ammonia in blood plasma and by changes in the relative weight of spleen (SSI).

The cortisol concentration in blood plasma, characterizing a primary reaction in our study, was the highest either at the beginning of handling, or of Transport I and III. A significant decrease of the cortisol concentration was found after 2 and 5 min period of keeping the fish in the air, as well as at the end of 10-hour Transport I. After the 2-hour Transport III, the cortisol concentration in blood plasma also decreased but this difference was non-significant. We anticipated that the primary reaction (the alarm reaction) started already during the period of harvesting the fish in the pond and during their transfer into tanks or transporting tanks (in case of Transport III) and during handling the 3-year-old marketable carp from the storage pond into the truck (in case of Transport I). Changes in the glucose concentration in blood plasma, representing the secondary reaction, were of the opposite character. Either after 2 and 5 min period of keeping the fish outside water, or after both 10- and 2-hour transport, the glucose concentration in blood plasma increased significantly. V an-Raaij et al. (1996) state that hyperglycaemia in such cases is probably a result of liver glycogenolysis stimulated by catecholamins and of stimulation of gluconeogenesis by cortisol during recovery. The negative correlation found between cortisol and glucose concentration in blood plasma of fish kept in the air for the 2 and 5 min period after catching also gives an evidence of the stimulation of gluconeogenesis by cortisol during recovery (Fig. 2).

While the onset of primary reaction (the alarm reaction) and of the secondary reaction (the adaptive reaction) was recorded in the above-mentioned experiments, the closing stage of the 10-hour Transport II can be classified as an exhaustion stage (Selye 1956). Death of the majority of fish was noticed at the end of Transport II. Stressors affecting the fish before and in the course of the transport were lethal. It concerned, above all, transport of fish with heavily filled digestive tracts. Already before the transport, these fish had increased cortisol concentrations and significantly increased glucose and ammonia concentrations in blood plasma compared to fish with chyme remnants in their digestive tract. Moreover, fish with heavily filled digestive tracts have much higher oxygen demands than those with empty digestive tract (Pokorný et al. 1998). Transfer the fish from $20{ }^{\circ} \mathrm{C}$ pond water into the storage pond, followed by handling them into the truck with $15^{\circ} \mathrm{C}$ water was another potent stressor acting already in the pre-transport phase. Moreover, in the storage pond there was a very low oxygen saturation $(16 \%)$. Such stress factors result in disbalance in the ammonia production and excretion (Evans 1993; Konovets et al. 1993; De-Boeck et al 1995; S vobodová et al. 1997a), leading to fish autointoxication by ammonia. Unfortunately, this hypothesis could not be confirmed at the end of the transport as the fish were dead. Part of fish which survived were those with chyme remnants in their digestive tracts. The ammonia concentration in blood plasma of these fish was practically identical with that found before the transport in fish with chyme remnants in their digestive tracts. The fish that had survived this 10-hour transport were in the secondary adaptative phase, as evidenced by the high glucose concentration found in their blood plasma (Fig. 5b). 
Considering the effect of Menocain anaesthetic, cortisol concentration in blood plasma of both the control and anaesthetised fish was nearly identical. On the contrary, the glucose concentration in blood plasma of fish in anaesthesia was significantly lower compared to the control group. This is important, above all, from the point of view of preventing the depletion of energy reserves of fish. Anaesthesia generally lowers the mobilization of energy resources which, in case of not using anaesthesia during a handling stress e.g. in artificial reproduction, would drop strongly. Similar results were shown by Jeney et al. (1986) when testing the anaesthetics Propanidid and MS 222 for artificial reproduction of the common carp.

Results of this work enable to recommend the following preventive measures in order to limit losses and damage of fish during transport:

Preparation of fish for the transport (above all emptying of the digestive tract).

Minimum pre-transport handling.

Identical water temperature in ponds from where the fish are caught, tanks where they are kept and the transporting tanks.

O Optimum water quality in tanks in which the fish are kept prior to the transport and in the transporting tanks (considering above all the oxygen concentration).

O Use of anaesthetics in fish manipulation, mainly in artificial reproduction, is an important preventive measure limiting the negative effects of this stressor.

\section{Vliv manipulace a transportu na koncentraci kortizolu a glukózy v krevní plazmě kapra obecného}

Cílem předkládané práce bylo zhodnotit stupeň stresové zátěže u kapra obecného (Cyprinus carpio, L.) vystaveného manipulaci a transportu. Jako indikátory stresu byly použity koncentrace kortizolu a glukózy $\mathrm{v}$ krevní plazmě, $\mathrm{v}$ některých případech koncentrace amoniaku v krevní plazmě a relativní hmotnost sleziny (SSI). V rámci manipulace byl sledován vliv časové prodlevy - pauzy ( $0 ; 2$ a 5 minut) mezi vylovením ryb z vody a odběrem krve na indikátory stresu. Cílem sledování bylo také ovlivnění indikátorů stresu anestetikem Menocain. Transport ryb byl uskutečněn v otevřeném systému přepravy ryb, a to jako 10-ti hodinový ve speciálním kamionu pro dálkovou přepravu živých ryb (transport I. a II.) a jako 2-hodinový v klasických přepravních bednách (transport III.). $\mathrm{V}$ průběhu transportu byla měřena teplota a koncentrace kyslíku ve vodě. Při manipulaci s rybou před odběrem krve (časová prodleva 2 a 5 minut) došlo k signifikantnímu snížení koncentrace kortizolu a k signifikantnímu zvýšení koncentrace glukózy ve srovnání s hodnotami naměřenými u ryb s odběrem krve ihned po vylovení. Vliv anestetika na koncentraci kortizolu nebyl prokázán. Naproti tomu koncentrace glukózy anestezované skupiny ryb byla signifikantně snížena. Po 10-hodinovém transportu ve speciálním kamionu (I.) byl zjištěn signifikatní pokles koncentrace kortizolu a signifikantní nárůst koncentrace glukózy v krevní plazmě. V průběhu 10-hodinového transportu ve speciálním kamionu (II.) došlo k úhynu převážné části kaprů. Příčina úhynu byla pravděpodobně udušení a autointoxikace amoniakem jako důsledek nakládky ryb s plným trávicím traktem. Po 2-hodinovém transportu v přepravních bednách (III.) došlo k nevýznamnému poklesu koncentrace kortizolu a relativní hmotnosti sleziny (SSI) a k signifikantnímu zvýšení koncentrace glukózy v krevní plazmě Výsledky ukázaly, že manipulace a transport jsou významnými stresovými zátěžemi kapra obecného. Byla navržena preventivní opatření snižující negativní účinky těchto zátěží.

\section{Acknowledgements}

This research was supported by the Czech Ministry of Agriculture, in part by Grant No IE 0940964009, and Grant No IE 0960996051. Mrs. Anna Kocová and Ing. Petr Svepeš are gratefully acknowledged for skillful technical assistance. 


\section{References}

BARRY, T. P., LAPP, A.F., KAYES, T. B., MALISON, J. A. 1993: Validation of microtitroplate ELISA for measuring cortisol in fish and comparison of stress response of rainbow trout (Oncorhynchus mykiss) and lake trout (Salvelinus namaycush). Aquaculture 117: 351-363

BARTON, B. A., PETER, R. E. 1982: Plasma cortisol stress response in fingerling rainbow trout, Salmo gairdneri Richardson, to various transport conditions, anesthesia, and cold shock. J. Fish. Biol. 20: 39-51

BARTON, B. A., PETER, R. E., PAULENCU, CH. R. 1980: Plasma cortisol levels of fingerling rainbow trout (Salmo gairdneri) at rest, and smoltification in Coho salmon, Oncorhynchus kisuth.Gen. Comp. Endocrinol. 59: 468-471

BARTON, B. A., SCHRECK, C. B., EWING, R. D., HEMMINGSEN, A. R., PATTINO, R. 1985: Changes in plazma cortisol during stress and smoltification in Coho salmon, Oncorhynchus kisutch. Gen. Comp. Endocrinol. 59: 468-471

CARRAGHER, J. E., RESS, C. M. 1994: Primary and secondary stress responses in golden perch Masquaria ambigua. Comp. Biochem. Physiol. 107A: 49-56

DE-BOECK, G., DE-SMET, H., BLUST, R. 1995: The effect of sublethal levels of copper on oxygen consumption and ammonia excretion in the common carp (Cyprinus carpio, L.). Aquat. Toxicol. 32: 124-141

EVANS, D. H. 1993: Physiology of Fishes. Marine Science Series, Boca Raton, 592 pp.

FRYER, J. N. 1975: Stress and adrenocorticoid dynamics in the goldfish Carassius auratus. Can. J. Zool. 53: 10121020

GRATZEK, J. B., REINERT, R., 1984: Physiological responses of experimental fish to stressful condition. In: Use of small fish species in carcinogenity testing. National Center Institute, Maryland, pp. 187 - 193

HLAVOVÁ, V. 1992: Reproduction as a stress on the fish organism. In: Adámek, Z., Flajšhans, M.: Proc. of Conference Fish Reproduction, RIFCH Vodňany, pp. 144-146

CHEN, G.-R., SUN, L.-T., LEE, Y.-H., CHANG, CH.-F. 1995: Characteristics of blood in common carp, Cyprinus carpio, exposed to low temperatures. J.Appl. Aquacult. 5: 21 - 32

JENEY, Z., JENEY, G. 1992: Primary and secondary stress responses of common carp (Cyprinus carpio L.) caused by artificial propagation. In: Adámek, Z., Flajšhans, M.: Proc. of Conference Fish Reproduction, RIFCH Vodňany, pp. 27-30

JENEY, Z., JENEY, G., OLAH, J., NEMCSOK, J., HORVATH, J. S. 1984: Effect of thermal stress on noradrenalin level in different organs, serum glucose level and serum GOT, GPT, GLDH and acetylcholinesterase activity of common carp (Cyprinus carpio L.). 16th Meeting of the Federation of European Biochemical Societies, p. 440

JENEY, Z., JENEY, G., OLAH, J., SIWICKI, A. DANKO, I. 1986: Propaninid, a new anaesthetic for use in fish propagation. Aquaculture 54: 149 - 156

KONOVETS, I. M., GRUBINKO, V. V., ARSAN, O. M., KULIK, V. A. 1993: Effect of temperature on the functioning of adaptive ammonia detoxification systems in carp. Gidrobiol. Zh. 29: 47 - 52

KRÁL, J., SVOBODOVÁ, Z. 1990: Menocain: čs. anestetikum pro ryby. Metodika VÚRH Vodňany, č.37, 7 pp. (in Czech)

LEATHERLAND, J. F., Woo, P. T. K. 1998: Fish diseases and disorders. Vol. 2 Non-infectious disorders. CABI Publishing, $386 \mathrm{pp}$.

LEBEDĚVA, N. E., GOLOVKINA, T. V., EL-GARABAVEY, M. M. 1989: Initial stress and change in the electrolyte content of mucus of carp, Cyprinus carpio. J. Ichtyol. 29: 34-41

LUSKOVÁ, V., LUSK, S. 1995a: Enzyme activities in the blood plasma of nase, Chondrostoma nasus, during spawning. Folia Zool. 44: 131-136

LUSKOVÂ, V., LUSK, S. 1995b: Enzyme activities in the blood plasma of brown trout, Salmo trutta m. fario, during spawning. Folia Zool. 44: 81-89

MAZEAUD, M. M., MAZEAUD, F., DONALDSON, E. M., 1977: Primary and secondary effects of stress in fish: some new data with a general review. Trans. Amer. Fish Soc. 106: 806 - 813

OLSEN, Y. A., EINARSDOTTIR, I. E., NILSSEN, K. J. 1995: Metomidate anaesthesia in Atlantic salmon, Salmo salar, prevents plasma cortisol increase during stress. Aquaculture 134: 155-168

PALÍKOVÁ, M., SVOBODOVÁ, Z. 1995: Biologické indikátory stresu u ryb (přehled). Bulletin VÚRH Vodňany, 31: 17-27 (in Czech)

PICKERING, A. D., 1981: The concept of biological stress. In: Stress and fish. Academic Press, London and New York, pp. 2-9.

POKORNÝ, J., ADÁMEK, Z., DVOŘÁK, J., ŠRÁMEK, V. 1998: Pstruhařství. Informatorium, Praha, 242 pp. (in Czech)

SELYE, H. 1956: The stress of life. McGraw-Hill Book Co., Inc., New York, Toronto, London, 328 pp.

SMITH, G. L., HATTINGH, J. 1978: The effect of respiratory stress on carp haemoglobin. Comp. Biochem. Physiol. 59A: 396-374

SPURNÝ, P., JIRÁSEK, J., MACHOVÁ, Z. 1984: Vliv stresových faktorů na některé biochemické ukazatele krve plůdku kapra. Živoč výr. 29: 1007-1014 (in Czech, English Summary)

SPURNÝ, P., JIRÁSEK, J., MAREŠ, J. 1987: Vliv manipulace při výlovu a krátkodobého transportu na stresové reakce organismu kapř́ho plůdku. Živoč. výr. 32: 877-883 (in Czech, English Summary) 
SPURNÝ, P., MAREŠ, J. 1997: Působení nepříznivých faktorů prostředí na rybí organismus. Sborník ze semináře Ochrana zdraví ryb. VÚRH JU Vodňany, pp. 159-165 (in Czech, English Summary)

SVOBODOVÁ, Z., GROCH, L., MÁCHOVÁ, J., VYKUSOVÁ, B. 1997a: Úhyn tržních kaprů na sádkách v Tachově. Sborník z konference Toxicita a biodegradabilita odpadủ a látek významných ve vodním prostředí. VÚRH JU Vodňany, Aquachemie Ostrava, pp. 168-175 (in Czech, English Summary)

SVOBODOVÁ, Z., KOLÁŘOVÁ, J., KOUŘIL, J., HAMÁČKOVÁ, J., VYKUSOVÂ, B., KALÁB, P. 1997b: Haematological investigations in Silurus glanis L. females during pre- and postspawning period. Pol. Arch. Hydrobiol. 44: 67-81

SVOBODOVÁ, Z., KOLÁŘOVÁ, J., MÁCHOVÁ, J., KALÁB, P., PIAČKA, V., VYKUSOVÁ, B., MODRÁ, H., DUŠEK, L., RAAB, O. 1998. Changes of haematological parameters of common carp during pond harvesting and storage. Ichthyohaematology - 4th Conference, RIFCH USB Vodñany, pp. 48-56

SVOBODOVÁ, Z., KOLÁŘOVÁ, J., VYKUSOVÁ, B. 1997c: Stres u ryb vznikající př́i běžných technologiích chovu. Ochrana zviŕat a welfare, VFU Brno, pp. 60-64 (in Czech)

SVOBODOVÁ, Z., PRAVDA, D., PALÁČKOVÁ, J. 1991: Unified methods of haematological examination of fish. Research Institute of Fish Culture and Hydrobiology, Vodňany, Edition Methods, No. 22, 31 p.

THOMAS, P. 1990: Molecular and biochemical responses of fish to stressors and their potencial use in environmental monitoring. Biological indicators of stress in fish. American Fisheries Society Symposium 8: 928

THOMAS, P., ROBERTSON, L. 1991: Plasma cortisol and glucose stress responses of red drum to handling and shallow water stressors and anesthesia with MS-222, guanidin sulfate and metomidate. Aquaculture 96: 69-89

VAN-RAAIJ, M. T. M., VAN-DEN-THILLART, G. E. E. J. M., VIANEN, G. J., PIT, D. S. S., BALM, P. H. M., STEFFENS, A. B. 1996: Substrate mobilization and hormonal changes in rainbow trout (Oncorhynchus mykiss, L.) and common carp (Cyprinus carpio, L.) during deep hypoxia and subsequent recovery. J. Comp. Physiol. 166: 443 - 452

WEDEMEYER, G. A., MCLEAY, D. J., 1981: Methods for determining the tolerance of fishes to environmental stressors. In: Stress and Fish. Academic Press, London and New York, pp. 246 - 275

WAGNER, E. J., DRISCOLL, D. M. 1994: Physiological stress responses of cutthroat to loading by fish pump, conveyer or dip net. J. Appl. Aquacult. 4: 19-28

WURTS, W. A. 1995: Using salt to reduce handling stress in channel catfish. World Aquaculture 56: 80-81

YIN, Z., LAM, T. J., SIN, Y. M. 1995: The effects of crowding stress on the non-specific immune response in fancy carp (Cyprinus carpio L.). Fish Shellfish Immunol. 5: 519-529 